ЛЮБОВ ГОНЧАР, кандидат економічних наук, дочент кафедри обліку і аудиту, ДВНЗ "Донбаський державний педагогічний університет", Украӥна ORCID Id 0000-0003-4014-2372 fox877@ukr.net

\title{
МОНІТОРИНГ СФОРМОВАНОСТІ КУЛЬТУРИ ПРОФЕСІЙНӦ̈ ДІЯЛЬНОСТІ МАЙБУТНІХ МЕНЕДЖЕРІВ
}

\author{
LIUBOV HONCHAR, Candidate of economic Sciences, \\ Associate Professor, Associate Professor, Chair of \\ Accounting and Auditing SHEI "Donbas State \\ Pedagogical University", Ukraine
}

\section{MONITORING OF FORMATION OF THE CULTURE OF PROFESSIONAL ACTIVITY OF FUTURE MANAGERS}

\begin{abstract}
У статті подано визначення поняття "культура професійної діяльності майбутнього менеджера". Для з'ясування рівня сформованості культури професійної діяльності здійснено моніторинг сформованості цього інтегрального утворення у майбутніх менеджерів. Виділено показники культури професійної діяльності. Висвітлено ефективність та важливість використання зазначених показників упроцесі формування професійної культури майбутніх менеджерів.
\end{abstract}

Ключові слова: культура професійної діяльності, студенти, майбутні менеджери, цінності професійного життя, професійна спрямованість.

Summary. The article defines the concept of "culture of professional activity of the future manager". In order to find out the level of professional culture formation, future managers have been monitored for this integrated education. Indicators of professional activity culture are highlighted. The efficiency and importance of using these indicators in the process of forming the professional culture of future managers are highlighted.

Key words: professional culture, students, future managers, values of professional life, professional orientation.

Мета: здійснити моніторинг проблеми формування культури професійної діяльності майбутніх менеджерів.

(C) Л. Гончар
Постановка проблеми в загальному вигляді. Динамічність розвитку українського суспільства активізує потребу в необхідності здійснювати через практико-орієнтований експериментальний пошук можливостей організації спеціальних заходів щодо формування професійних умінь і навичок, культури професійної діяльності майбутніх менеджерів. Закономірно, щоб цей процес був ефективним, викладачу слід проводити моніторинг розвитку мотиваційної сфери студентів, рівня сформованості в них культури професійної діяльності.

Аналіз досліджень і публікацій. Проблема формування професійної культури відображається у працях С. Анеліної, С. Вітвицької, В. Гриньової, В. Мазіна, І. Михайліченка, І. Радомського та інших. Теоретичні питання і шляхи підготовки майбутніх менеджерів висвітлено в роботах таких науковців, як В. Горланчук, І. Дороховського, І. Черноіванова, П. Друкера, В. Зобова та інших. Форми і методи розвитку професійних умінь розглядаються в дослідженнях С. Гончаренка, О. Дубасенюк, Н. Ничкало, О. Пєхоти. Результати вивчення проблеми названими фахівцями були основоположними в розробленні концептуальних засад нашого дослідження.

Виклад основного матеріалу дослідження. Культуру професійної діяльності визначаємо як інтегральне особистісне утворення в сукупності норм, цінностей, способів поведінки, прийнятих у соціумі, комунікативних умінь і навичок, що забезпечують можливість здійснення міжособистісної взаємодії у вирішенні професійних завдань, здатності управляти організацією та іiї підрозділами, працювати в команді, адаптуватись та діяти в новій ситуації. Показниками культури професійної діяльності майбутніх менеджерів нами обгрунтовано: розуміння сутності культури професійної діяльності майбутнього менеджера, механізмів їх прояву та усвідомлення необхідності їх виявлення у професійній діяльності; орієнтація на формування культури професійної діяльності, ціннісне ставлення до корпоративних норм, правил прийнятих у соціумі; свідомо регульована діяльність, поведінка, спілкування на основі професійно значущих норм, правил; творчий характер вирішення професійних ситуацій, партнерської взаємодії, спілкування, варіативність поведінки.

З метою дослідження рівнів сформованості культури професійної діяльності майбутніх менеджерів, а також з'ясування чинників, які впливають на неї, нами проведено констатувальний експеримент. Зокрема, для з'ясування прояву культури професійної діяльності у взаєминах нами проведено опитування 49,4\% респондентів ЕГ. $51,2 \%$ КГ зазначили, що виявляють культуру професійної діяльності у взаєминах завжди; 38,8\% опитаних ЕГ, $39,4 \%$ опитаних КГ зізнаються, що виявляють культуру професійної діяльності іноді, залежно від обставин, 
ставлення до конкретної людини, а також акцентують увагу на невмінні контролювати свої емоції у взаєминах, $11,8 \%$ опитаних ЕГ і 9,4\% КГ не дають відповіді на це запитання, що наштовхує на не досить втішні висновки щодо розуміння і розвитку в майбутніх менеджерів цього інтегрального особистісного утворення.

Крім того, майбутні менеджери критично оцінюють рівень сформованості культури професійної діяльності своїх одногрупників, підкреслюючи, що у взаєминах з іншими їм не вистачає доброзичливості, порядності, культури спілкування, чуйності, тактовності, професіоналізму, соціально-професійної мобільності, організаторських умінь, ораторського мистецтва. Причинами таких непорозумінь вони вважають: низький рівень розвитку в них загальної і комунікативної культури; відмінності в інтересах, цінностях; небажання прийняти позицію іншого; невміння контролювати власні емоції і поведінку; прагнення самоствердитися за рахунок іншого. Викладачі також вказують на низький рівень сформованості культури професійної діяльності в майбутніх менеджерів, що виявляється у відсутності взаєморозуміння, творчості, поміркованості, ерудованості, відповідальності, щирості, вияві у їх поведінці байдужості, агресивності, невмінні поступатися, егоцентричності.

Застосування методики незакінчених речень дозволило з'ясувати характер ставлення студентів до майбутньої професійної діяльності та виявити розуміння ними рівня ціннісного підходу до майбутньої професійної діяльності. За результатами оцінки можна зробити висновок, що для $64,3 \%$ ЕГ опитаних і $68,2 \%$ КГ розвиток культури професійної діяльності не є домінуючим, їх життя зорієнтоване переважно на досягнення у подальшому певних матеріальних благ, вони не дотримуються соціальних норм і правил поведінки у взаєминах, не вміють поводитися в конфліктних ситуаціях, у них недостатньо розвинуті або взагалі відсутні якості лідера, уміння та навички слухати і чути свого співрозмовника.

Проведений моніторинг щодо ставлення майбутніх менеджерів до основних цінностей професійної діяльності засвідчив про їх в основному прагматичну орієнтацію у виборі майбутньої професії. Зокрема, професійна діяльність у розумінні сту- дентів - це сфера, яка дозволяє отримати прибуток, забезпечує комфортне, благополучне життя, дозволяє стати відомим, зажити слави; це також сфера, де можна успішно й довго просуватися в діяльності. Можливість мати надійних друзів, установлювати емоційно насичені взаємини, задовольнити потребу у спілкуванні та високі індивідуальні досягнення отримали найнижчу кількість виборів студентів. Крім того, на формування професійної діяльності, на думку молоді, впливають: гроші - 20,8\% ЕГ, 21,5\% КГ ; знання - 14,7\% ЕГ, 12,8\% КГ ; зв'язки - 6,9\% ЕГ, 5,4\% КГ; вміння працювати $-7,1 \%$ ЕГ, 7,2\% КГ; наполегливість - 2,9\% ЕГ, 5,7\% КГ; везіння2,3\% ЕГ, 2,7\% КГ; сила волі-5,9\% ЕГ, $8,7 \%$ КГ; наявність розвинутих професійних умінь і навичок обрали лише $13,7 \%$ студентів ЕГ, 13,9\%-КГ.

Визначення рівнів професійної спрямованості майбутніх менеджерів здійснювалося за допомогою методики "Визначення рівня професійної спрямованості" (за Т. Дубовицькою). Зокрема, 24,5\% опитаних ЕГ, 27,3\% КГ мають високий рівень професійної спрямованості. Вони виявляють інтерес до майбутньої професійної діяльності, мають бажання активно здобувати знання і навички, досягнути успіхів в обраній професійній діяльності. Низький рівень професійної спрямованості спостерігається у 29,4\% респондентів ЕГ і 28,6\% КГ, що вказує на відсутність зацікавленості і привабливості майбутньої професійної діяльності, перевагу зовнішньої мотивації у процесі вибору майбутньої спеціальності, небажання працювати за обраною спеціальністю. Для переважної більшості майбутніх менеджерів (46,1\% опитаних ЕГ, 44,1\% КГ) привабливість майбутньої професії знаходиться на достатньому рівні, що вказує на сумніви у власних професійних здібностях за наявності загального позитивного ставлення до майбутньої професійної діяльності та недостатнє усвідомлення власного місця в обраній галузі.

Слід зазначити, що освітню діяльність майбутніх менеджерів можна умовно представити як діяльність 3 вирішення пізнавальних завдань та проблем, у свою чергу, її мотивами $\epsilon$ знання і способи їх набуття, які виявляються у процесі оволодіння засобами майбутньої професійної діяльності. Професійну діяльність майбутніх менеджерів також можна умовнопредставити як діяльність з вирішен- ня практичних завдань та проблем. Професійними мотивами тут виступають виробництво і перетворення продукту праці в модельній формі. 3 огляду на це формування мотивів професійної діяльності у процесі оволодіння знаннями надає поштовх особистісному професійному змісту, який закладено в навчальних та професійних завданнях або проблемах.

3 метою визначення мотивації професійної діяльності майбутніх менеджерів використано методику К. Замфіра в модифікації А. Раєна "Мотивація професійної діяльності". У процесі дослідження студентам було запропоновано заповнити бланк із запитаннями за наступною шкалою відповідей: 1 бал - значною мірою; 2 бали - достатньо незначною мірою; 3 бали - невеликою, але й не малою мірою; 4 бали - достатньо великою мірою; 5 балів - дуже великою мірою. На основі отриманих результатів нами визначено мотиваційні комплекси студентів. До найкращих, оптимальних, мотиваційних комплексів слід відносити такі два типи сполучень: ВМ $>3 \Pi \mathrm{M}>3 \mathrm{HM}$ i $\mathrm{BM}=3 \Pi \mathrm{M}>3 \mathrm{HM}$. Найгіршим мотиваційним комплексом вважаємо тип ЗНМ > ЗПМ > ВМ, у яких ВМ (внутрішня мотивація), ЗПМ (зовнішня позитивна мотивація) і ЗНМ (зовнішня негативна мотивація). Між цими комплексами укладені проміжні (з точки зору їх ефективності) мотиваційні комплекси. Однак, зазначимо, що під час інтерпретації слід ураховувати не лише тип мотиваційного комплексу, але й те, наскільки сильно один тип мотивації перевершує інший за ступенем вираженості (Райгородский, 2002).

Згідно з отриманими даними, оптимальні мотиваційні комплекси, які представлені поєднаннями: ВМ > 3ПМ > ЗНМ і BM = 3ПМ > 3НM, обрала найменша кількість майбутніх менеджерів. Тобто, за нашими підрахунками, для 13,9\% опитаних ЕГ, 15,2\% КГ переважаючим типом мотивації професійної діяльності є внутрішній. Такі студенти залучаються до навчання заради отримання майбутньої професії, а не задля досягнення зовнішніх винагород; вони проявляють інтерес до самого навчання та схильні вибирати складні завдання, що в кінцевому результаті має вагомий вплив на розвиток їх пізнавальних процесів. Наявність внутрішніх спонукальних мотивів сприяє прояву в майбутніх менеджерів оригінальності, креативності, творчості й розкутості. Крім 
того, 3,4\% ЕГ студентів, 2, $1 \%$ КГ обрали проміжний мотиваційний комплекс ВМ = ЗПМ = ЗНМ. Це свідчить, що майбутні менеджери цікавляться діяльністю, яку вони обрали, а також виявляють бажання досягнути певних зовнішніх винагород.

Найгірші мотиваційні комплекси представлені поєднаннями: ЗНМ> 3ПМ> ВM; 3НM> 3ПМ = ВM; 3HM> ВМ> ЗПМ обрала найбільша кількість опитаних (54,7\% ЕГ, 51,3\% КГ). Отриманий результат можна пояснити, на наш погляд, $з$ одного боку - прагненням підтвердити свою дорослість і незалежність, а $з$ іншого - недостатнім розвитком пізнавального інтересу в певної частини студентів. Для таких студентів характерним $є$ байдуже, негативне ставлення до процесу навчання й вибору професії загалом. Ціннісні орієнтації цих студентів спрямовано не на набуття професійних знань й умінь, а отримання диплому.

Спонукальними мотивами вступу до закладу вищої освіти таких студентів $є$ відсутність внутрішньої мотивації та такі причини, як: не вступив до іншого 3ВО, за прикладом або разом з товаришем, за вказівкою батьків тощо. У свою чергу, відсутність внутрішньої мотивації сприяє зростанню в них напруженості, спонтанності, тривожності, унеможливлює прояв творчості і креативності. Для цих осіб характерна зовнішня мотивація, до освітньої діяльності їх спонукає можливість отримання вигоди (матеріальні, соціальні, психологічні) або бажання уникнути неприємностей; вони не мають сформованої професійної спрямованості, а отже, відзначаються низькою культурою професійної діяльності; не виявляють інтересу до самого навчання та схильні обирати прості завдання, виконують необхідний мінімум для отримання оцінки.

У $31,4 \%$ опитаних ЕГ, 33,5\% КГ переважає зовнішня позитивна мотивація. За даного типу мотиваційного комплексу у студентів досить посередньо виражений мотив "отримання знань", мотивація до здобуття знань дещо занижена, їх приваблює не сама діяльність, а те, як вона буде оцінена оточуючими (позитивна оцінка, заохочення, похвала тощо).

Однією з важливих складових формування культури професійної діяльності мотиваційно-ціннісного компонента є готовність майбутніх менеджерів до ризику, тобто спроможність діяти в ситуаціях невизначеності, приймати зважені управлінські рішення, що здійснюватиме вплив на професійну самореалізацію та ефективність здійснення господарської діяльності. Зокрема, у своїй професійній діяльності майбутні менеджери зіштовхуються із ситуативним (мотивованим) та немотивованим ризиками. Так, якщо особистість свідомо ризикує задля досягнення певних вигод (схвалення, самоствердження тощо), вона має справу 3 мотивованим ризиком, якщо на досягнення вигод впливають зовнішні умови, події, непередбачувані обставини, тоді йдеться про справу з немотивованим ризиком.

3 огляду на це 3 метою визначення схильності майбутніх менеджерів до ризику, здатності в умовах невизначеності та нестандартних ситуаціях приймати правильні, обгрунтовані рішення нами застосовано методику діагностики рівня готовності до ризику $(P$. Шуберта). Методика містить 25 тверджень (Кокун, 2011). Так, у процесі дослідження встановлено, що яскраво виражену готовність до ризику мають $25,4 \%$ опитаних ЕГ, $28,3 \%$ КГ, що свідчить про, що, незважаючи на рішучість дій та швидкість у ризикових ситуаціях, такі студенти не прогнозують прийняті рішення й не задумуються про ефективність їх наслідків. Невиражений (базовий) рівень готовності до ризику прослідковується у $26,2 \%$ опитаних ЕГ, 27,2\% КГ. Такі майбутні менеджери не можуть швидко реагувати на проблеми, що виникають, і приймати обгрунтовані управлінські рішення, що негативно позначиться у майбутньому на ефективності та результативності здійснення професійної діяльності. 48,4\% респондентів ЕГ, 44,5\% КГ мають достатній рівень готовності до ризику у професійній діяльності. Вони обгрунтовано підходять до прийняття виважених управлінських рішень в умовах невизначеності; ризики, у їх розумінні, мають бути виправданими, що наближує до більш виваженої мотивації у прийнятті рішень.

Зазначимо, що культура професійної діяльності виявляється у дотриманні корпоративних норм і цінностей організації, оскільки корпоративна культура $є$ системою формальних і неформальних правил та норм діяльності, відповідних звичаїв і традицій, індивідуальних та колективних інтересів в організації. Цей вид культури впливає на ступінь задоволеності індивіда умовами праці, визначає особливості поведінки працівників, їх взаємодію, стиль керівництва та колективне бачення перспектив розвитку. Її елементами (напрямами роботи) є: цінності, ідентичність, символіка, поведінка, розвиток переконання (Карамушка, 2015, с. 42-43).

Рівні сформованості праксичного компонента культури професійної діяльності майбутніх менеджерів визначалися нами за допомогою спеціального тестуна підставі класифікації Ч. Хенді (Хенді, 2012). Дослідник виділив чотири типи корпоративної культури, кожному з них присвоївши ім'я відповідного олімпійського бога:

1) культура влади, або Зевса. Ї̈̈ суттєвий момент - особиста влада, джерелом якої є володіння ресурсами. Організації, які сповідують таку культуру, мають жорстку структуру, високий ступінь централізації управління, нечисленні правила і процедури, пригнічують ініціативу працівників, здійснюють жорсткий контроль над усім. Успіх тут визначається кваліфікацією керівника і своєчасним виявленням проблем, що дозволяє швидко приймати і реалізовувати рішення. Така культура характерна для молодих комерційних структур;

2) рольова культура, або культура Аполлона. Це бюрократична культура, що базується на системі правил і інструкцій. Їй властиво чіткий розподіл ролей, прав, обов'язків і відповідальності між працівниками управління. Вона негнучка і ускладнює нововведення, тому малоефективна в умовах змін. Джерелом влади в даному випадку виступає посада, а не особисті якості керівника. Така управлінська культура характерна для великих корпорацій і державних установ;

3) культура завдання, або культура Афіни. Вона пристосована до управління в екстремальних умовах $\mathrm{i}$ постійно мінливих ситуаціях, тому основна увага приділяється швидкості вирішення проблем, що грунтується на співпраці, колективному виробленні ідей та спільних цінностях. Фундаментом влади є знання, компетентність, професіоналізм і володіння інформацією. Це перехідний тип управлінської культури, здатний перерости в один з попередніх. Він властивий проєктним і венчурним організаціям;

4) культура особистості, або культура Діоніса. Вона пов'язана з емоційним початком і грунтується на творчих цінностях, об'єднуючи людей не для вирішення службових завдань, а для досягнення індивідуальних цілей. Рішення приймаються на основі згоди, тому влада має координаційний 
характер (Хенді, 2012).

У процесі дослідження студентам було запропоновано надати фіксовані оцінки різним аспектам культури. Результати опитування майбутніх менеджерів дали змогу з'ясувати розподіл виявів корпоративної культури за типами та визначити, як цей розподіл виглядає в ідеальному (сприятливому) варіанті умов діяльності. Згідно з результатами вивчення 28,5\% респондентів ЕГ та 21,6\% КГ надають перевагу культурі влади, або "Зевса". Їм властива схильність до інтуїтивного мислення; навчаються методом спроб та помилок; целюди дії, їх більше цікавлять учинки інших; розмірковують цілісно, оцінюючи повну картину відразу. Майбутні менеджери культури "Зевса" намагаються керувати людьми та діяльністю. Вони цінують гроші як засіб впливу для досягнення цілей, витрачають багато зусиль для створення та підтримки корисних зв'язків або знайомств. Інформацію для особистого розвитку студенти отримують у процесі неформального спілкування, а не на лекціях та семінаpax. $48,8 \%$ опитаних ЕГ та $49,4 \%$ КГ надали перевагу культурі ролей, або "Апполона". Для тих, хто обрав такий тип культури, важливе значення мають правила та інструкції. Студенти вважають, що у процесі здійснення майбутньої професійної діяльності вони мають виконувати чітко визначену роль, яка не виходить за вказані рамки і не відхиляється за її межі. Їм притаманне аналітичне, логічне та послідовне мислення, педантичність. Вони цінують упорядкованість та передбачуваність, однак вони, як правило, обмежені у проявах своєї індивідуальності.

Культуру завдань, або культуру "Афіни" обрали 14,8\% опитаних ЕГ, $12 \%$ КГ. Вони творчі, талановиті, цінують логічність та творчий підхід увиконанні будь-яких завдань, поважають професіоналізм та компетентність. У процесі вирішення проблем, зазвичай, орієнтуються на групове обговорення та дискутування. 22,7\% респондентів ЕГ і 24,5\% КГ обрали культуру особистості або культуру "Діоніса". Студенти цієї групи вважають, що в майбутній професійній діяльності важливими є професіоналізм, особистісна свобода, незалежність. Вони ототожнюють себе в роботі не з організацією та іії розвитком, а з професією, тобто бачать себе вільними працівниками, які тимчасово надаватимуть свої послуги клієнтам організації.

Висновки та перспективи подальших досліджень. Отже, як показали результати здійсненого моніторингу сформованості культури професійної діяльності майбугніх менеджерів, студенти мають недостатньо глибокі грунтовні знання щодо основних складових культури професійної діяльності. Для більшості культура професійної діяльності не виступає механізмом регулювання їхньої поведінки. Багатьом юнакам і дівчатам властиві спрямованість на себе, тяжіння до егоцентризму, низький рівень емпатії, що блокує розвиток у них соціально-комунікативних умінь. У них не сформовані навички саморегуляції поведінки, що проявляється у неконтрольованих діях, учинках; вони не володіють навичками ефективного розв'язання конфліктних ситуацій.

Узагальнення даних констатувального експерименту допомагає визначити цілі, конкретизувати завдання, підібрати форми і методи роботи для оптимізації формування культури професійної діяльності у юнаків і дівчат.

\section{СПИСОК ЛІТЕРАТУРИ}

Бакулина, О. С., Тернопольская, В. И. (2018). Особенности формирования профессиональной компетентности будущих специалистов по налогообложению и таможенному делу. Progress, 1-2, 94-97.

Карамушка, Л. М., Креденцер, О. В., Терещенко, К. В. (2015). Психологічні детермінанти розвитку організаційної культури. Київ : Педагогічна думка.

Кокун, О. М., Пішко, І. О., Лозінська, Н. С., Копаниця, О. В., Малхазов, О.
Р. (2011). Збірник методик для діагностики психологічної готовності військовослужбовців військової служби за контрактом до діяльності у складі миротворчих підрозділів. Київ : НДЦГП ЗСУ.

Райгородский, Д. Я. (2002). Практическая психодиагностика. Методики и тесты. Самара : ИД Бахрах-М.

Хенді, Чарльз (2012). По той бік впевненості. Про новий світ всередині і навколо організацій. Москва: Питер.

Ternopilska, V., Guk, O., Zavhorodnia, Y., Ryzhykov, V., Snitka, Y., Chernukha, N. (2019). Variants of the educational paradigm in training ofmanagers. Revista ESPACIOS, 40 (29), 9.

\section{REFERENCES}

Bakulina, O. S., Ternopol'skaja, V. I. (2018). Features of the formation of professional competence of future specialists in taxation and customs. Progress, 1-2, 94-97.

Karamushka, L. M., Kredencer, O. V., Tereshhenko, K. V. (2015). Psychological determinants of organizational culture development. Kiev : Pedagogical Thought.

Kokun, O. M., Pishko, I. O., Lozinsjka, N. S., Kopanycja, O. V., Malkhazov, O. R. (2011). Collection of methods for diagnostics of psychological readiness of military servicemen under contract for activities within the peacekeeping units. Kiev: SIC of the SSU.

Rajghorodskyj, D. Ja. (2002). Practical psychodiagnostics. Methods and tests. Samara : ID Bahrakh-M.

Khendi, Charljz (2012). Beyond confidence. About the new world inside and around organizations. Moscow : Peter.

Ternopilska, V., Guk, O., Zavhorodnia, Y., Ryzhykov, V., Snitka, Y., Chernukha, N. (2019). Variants of the educational paradigm in training of managers. Revista ESPACIOS, 40 (29), 9.

Стаття надійшла 3.03.2020 p. 